\title{
The effect of adding various fats to a force-fed diet on goose fatty liver
}

\author{
I. NIR *, A. DVORIN ** and ZAFRIRA NITSAN *** \\ * Department of Animal Science, The Hebrew University of Jerusalem, \\ Faculty of Agriculture, Rehovot, Israel \\ *** Akko Goose Breeding and Research Farm, P.O. Box 35, Akko, Israel \\ *** Division of Poultry Science, Agricultural Research Organization, \\ The Volcani Center, Rehovot, Israel
}

\begin{abstract}
Summary
Goose fat, poultry fat, beef tallow or soybean oil were each added separately to a basal diet $(10$ p. 100 soybean meal, vitamins and minerals brought to 100 p. 100 with corn). In 5 experiments geese were crammed with these fat supplemented diets or with the basal diet. Fat supplementation (2-5 p. 100) always increased liver weight by 10 p. 100. Goose and poultry fat allowed to shorten the cramming period and improved feed conversion and body weight gain. Beef tallow and soybean oil had no effect on the cramming period and soybean oil did not improve feed utilization. The fatty acid composition of the livers was not affected by supplementation with fat at the assayed levels.
\end{abstract}

\section{Introduction}

Supplementation of a maize diet with different nutrients increased the size (NIR, Nitsan \& KATZ, 1976) and improved the quality (NIR \& NitSAN, 1976) of the fatty liver in the crammed geese. Supplementation with soybean meal and minerals causes a reduction in the dietary energy. Since hepatic steatosis in the crammed goose is mainly due to excessive energy intake, addition of fat to the diet could be beneficial. Dietary fat may be detrimental to hepatic lipogenesis (Levellete et al., 1975). Studies conducted on ducks, force-fed with corn, led the authors to conclude that, in this species, liver steatosis is mainly due to insufficient transport of newly synthetized lipids (LECLERcQ \& BLUM, 1975). In the chick, dietary soybean oil accelerated lipid transport and reduced hepatic steatosis (ShapIRA, Nachtomi \& NIR, 1979).

The purpose of the present work was to study the effect of different fats added to the cramming diet on the fatty liver size, fatty acid composition of the liver fat, feed utilization and the duration of the cramming period. 


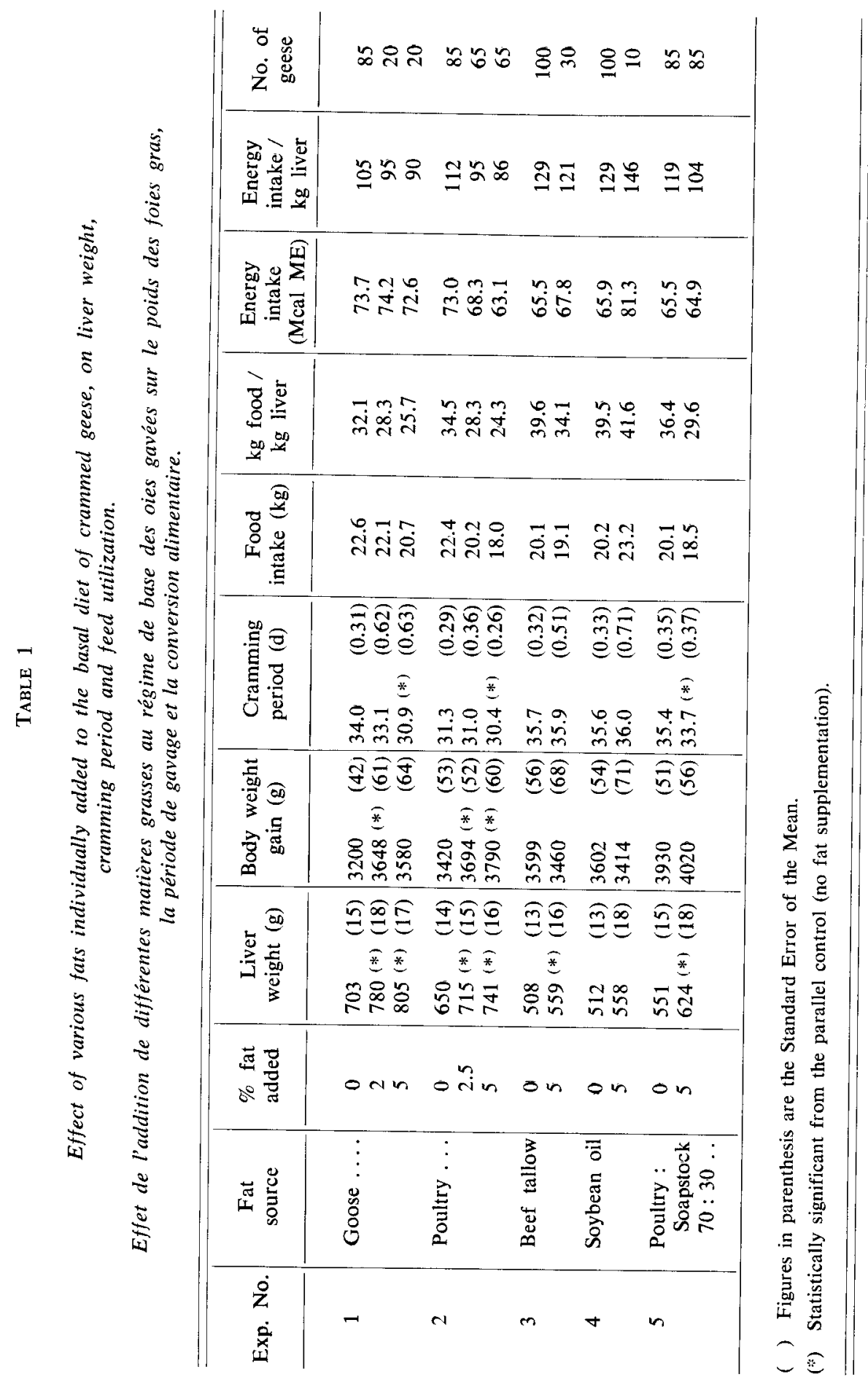




\section{Material and methods}

The geese used were of a local breed described by NIR \& PereK (1971). Cramming and processing after slaughter were described previously (NIR \& NitSAN, 1976). Body weights at start of cramming and at slaughter, and liver weights were recorded individually, food intake on a group basis.

At slaughter, liver samples were removed and frozen at $-20^{\circ} \mathrm{C}$. Following chloroform:methanol $(3: 1)$ extraction fatty acids were determined in dietary fats and livers by gas-liquid chromatography. The basal cramming diet was a pelleted feed composed of soybean meal, corn, vitamins and minerals (NIR, Nitsan \& KaTZ, 1976). Each experimental group was fed with the basal diet, on which one of the alternative fat supplement was sprayed. Metabolizable energy of the basal diet was calculated to be $3260 \mathrm{Kcal} \mathrm{ME} / \mathrm{kg}$ according to NRC (1977); that of the supplemented fats was estimated to be $8200 \mathrm{kcal} \mathrm{ME} / \mathrm{kg}$ for goose fat, poultry fat, soybean oil or acidulated soybean oil soapstock and $7100 \mathrm{Kcal} \mathrm{ME} / \mathrm{kg}$ for beef tallow.

Five experiments were conducted in which the different fats were supplemented at various levels. In each experiment the means of the control and of the treated groups were compared for statistically significant $(p<0.05)$ differences by Student's test (tabl. 1).

\section{Results and discussion}

Addition of the different fats at the level of 2 to 5 p. 100 increased the liver weight at slaughter by about 10 p. 100 (statistically significant difference except soybean oil). When goose and poultry fat (exp. 1,2) were supplemented, the increase in liver weight was concomitant to an increase in body weight gain (statistically significant difference), to a decrease in food intake (which was not always accompanied by a decrease in energy intake), to an improvement in feed and energy utilization and to a slight reduction in the cramming period (statistically significant difference in experiments 1 and 2 for the 5 p. 100 fat supplemented groups). These effects were also obtained when a mixture of poultry fat:acidulated soapstock $(70: 30)$ was added (exp. 5). Addition of tallow (exp. 3) and soybean oil (exp. 4) had non significant effect on the body gain and on the cramming period. Surprisingly, in the soybean oilsupplemented group, feed and energy utilization were reduced.

The fatty acid profiles of the added fats and of the fatty livers are shown in table 2. Those of the latter were quite similar to earlier data obtained in geese crammed with 95 p. 100 cooked corn and 5 p. 100 tallow (LeClerCQ et al., 1968) or with 97 p. 100 cooked corn and 3 p. 100 lard (BALdissera, 1971). When the fat added to the basal diet was limited to 5 p. 100 , its effect was minor upon fatty acid composition of liver lipids. Lipogenesis originating from excessive dietary carbohydrates was the main source of fatty acids and it reduced the effects of exogenous fats. Beef tallow is poorly digested by the chicken (Scott, Nesheim \& Young, 1976). A low digestibility of this fat by the crammed goose could explain the results brought here (exp. 3). The results obtained with soybean oil (exp. 4) are paradoxical and deserve further investiga- 


\section{TABLE 2}

Fatty acid composition of supplementary fats and of the liver fat obtained by feeding different diets, each including one of the supplements; one diet had no addition.

Composition en acides gras des graisses ajoutées au régime de base et des lipides hépatiques obtenus après gavage suivant les régimes.

\begin{tabular}{|c|c|c|c|c|c|c|c|c|}
\hline \multirow{2}{*}{$\begin{array}{l}\text { Supplemented } \\
\text { fats }\end{array}$} & \multicolumn{8}{|c|}{ Fatty acids } \\
\hline & $14: 0$ & $16: 0$ & $16: 1$ & $18: 0$ & $18: 1$ & $18: 2$ & $18: 3$ & $20: 4$ \\
\hline \multicolumn{9}{|c|}{$\%$ of total fatty acids } \\
\hline Goose & 0.49 & 23.6 & 4.1 & 8.0 & 54.2 & 9.5 & 一 & - \\
\hline Poultry & - & 22.9 & 10.2 & 5.1 & 42.1 & 17.2 & 0.8 & 一 \\
\hline Beef tallow. & - & 32.5 & 2.9 & 24.0 & 37.4 & 1.0 & - & 一 \\
\hline Soybean...$\ldots$. & - & 11.5 & 一 & 4.3 & 28.3 & 49.5 & 6.9 & - \\
\hline \multicolumn{9}{|c|}{ Livers (mean of $3-5$ livers per treatment) } \\
\hline $2 \%$ goose & 0.56 & 21.6 & 2,9 & 14.4 & 56.7 & 2.8 & - & - \\
\hline $5 \%$ goose & 0.44 & 21.5 & 2,7 & 14.9 & 57.6 & 2.2 & - & - \\
\hline $5 \%$ poultry. & - & 21.3 & 2.7 & 14.4 & 59.2 & 1.7 & - & 0.2 \\
\hline $5 \%$ tallow & - & 20.5 & 2.4 & 16.9 & 57.1 & 1.9 & - & 0.4 \\
\hline $5 \%$ soybean. & - & 21.1 & 2.3 & 16.2 & 56.8 & 2.6 & 0.1 & 0.4 \\
\hline No addition .. & 0.47 & 23.9 & 2.4 & 16.7 & 54.6 & 2.1 & - & - \\
\hline
\end{tabular}

tion. The depressing effect of unsaturated fatty acids on lipogenesis (LeveiLle et al., 1975 ) and their positive effect on the transport of hepatic lipids (ShapIRA, Nachtomi \& NIR, 1979) could be related to their poor utilization by the crammed goose for fatty liver production.

Accepté pour publication en décembre 1982.

\section{Résumé}

Effet de différentes matières grasses ajoutées à la nourriture des oies gavées, sur le foie gras

Différentes matières grasses (graisses d'oie et de poulet, suif et huile de soja) ont été ajoutées à une ration de base (tourteau de soja, 10 p. 100 ; minéraux, vitamines et maïs). Dans différentes expériences, les oies ont été gavées avec la ration de base ou avec les rations expérimentales. Les rations supplémentées en matière grasse ont entraîné une aug. mentation du poids des foies gras d'environ 10 p. 100 . Les graisses d'oie et de poulet ont amélioré le taux de conversion alimentaire et ont raccourci la période de gavage. L'addition 
de suif et d'huile de soja s'est révélée sans effet sur la période de gavage et l'huile de soja sans effet sur la conversion alimentaire. La composition des acides gras des fois gras ne correspondait pas à la composition des matières grasses ajoutées à l'aliment de base.

\section{References}

Baldissera Nordio C., 1971. Aspetti e possibilita dell' alevamento du palmipedi in italia con particulare riguardo alla produczione del fegato grasso. Delli atti delle giornale avicole varesine, 2, 121-161.

LeClerce B., BLum J.C., 1975. Etude de la suralimentation forcée : effets sur le métabolisme hépatique et les formes de transport hépatiques chez le canard. Ann. Biol. anim. Bioch. Biophys., 15, 559-568.

Leclerce B., Durand G., Delpech P., Blum J.C., 1968. Note préliminaire sur l'évolution des constituants biochimiques du foie au cours du gavage de l'oie. Ann. Biol. anim. Bioch. Biophys., 8, 549-556.

Leveille G.A., Romsos D.R., Yeh Y., O'Hea E.K., 1975. Lipid biosynthesis in the chick. A consideration of site of synthesis, influence of diet and possible regulatory mechanisms. Poult. Sci., 54, 1075-1093.

Nir I., Nitsan Z., 1976. Goose fatty liver composition as related to the degree of steatosis, nutritional and technological treatments and a simplified method for quality estimation. Ann. Zootech., 25, 461-470.

Nir I., Nirsan Z., KatZ Z., 1976. Recent developments in the diet used in cramming geese for the production of fatty liver. 5th European Poultry Conference, Malta. 5-11th September 1976. Published by W.P.S.A., 1, 476-474.

Nir I., Perex M., 1971. The influence of soybean meal supplemented to the maize diet of forced-fed geese upon their liver, organ and blood plasma components. Ann. Biol. anim. Bioch. Biophys., 12, 77-79.

N.R.C., 1977. National Research Council. Nutrient Requirements of Poultry. 7th ed. Washington, D.C., National Academy of Sciences, National Research Council, U.S.A.

Scott L.S., Nesheim M.C., Young R.J., 1976. Nutrition of the Chicken. M.L. Scott and Associates, Ithaca, New York, U.S.A.

Shapira N., Nachtomi E., NiR I., 1979. Effect of isocaloric supplements of glucose or soybean oil on lipids in tissues and plasma lipoproteins of starved and overfed chicks. Nutr. Metab., 23, 368-383. 